\title{
Effect of Plant Growth Regulators (PGRs) and Micronutrients on Flowering and Yield Parameters of Green Gram (Vigna radiate $\mathbf{L}$.)
}

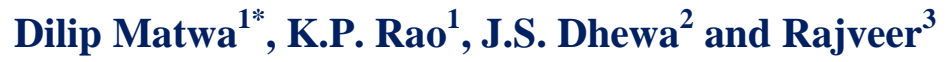 \\ ${ }^{1}$ Department of Biological Science, ${ }^{2}$ Department of Agroforestry, \\ ${ }^{3}$ Department of Soil Science, Sam Higginbottom Institute of Agriculture, Technology and \\ Sciences, Allahabad, 211007 U. P., India \\ *Corresponding author
}

\section{A B S T R A C T}

\section{Keywords}

Salicylic acid, Brassinolide, Zink, Boron, and Green gram.

Article Info

Accepted: 20 March 2017 Available Online: 10 April 2017
An experiment was conducted during Summer season 2016 to study the "Effect of Plant growth regulators (PGRs) and Micronutrients on flowering and yield parameters of Green Gram (Vigna radiate L.)" on central research farm department of biological science, SHIATS Allahabad. The soil of experimental area falls in order Inceptisol and soil texture was sandy loam. Two varieties of green gram i.e. IPM-0203 and Ganga-8 was used with different concentration of Plant Growth regulators salicylic acid 100, 200 ppm, Brassinolide $0.25,0.50 \mathrm{ppm}$, zink $100 \mathrm{ppm}$ and boron $100 \mathrm{ppm}$ of each concentration and one respective control was used. The best treatment was $\mathrm{T}_{3}$ (Brassinolide $0.25 \mathrm{ppm}$ ) showed the significant increase on number of flowers per plant (39.30), flower fruit ratio (72.67\%), pollen viability $(70 \%)$, number of pods per plant $(28.70)$, pod weight per plant $(11.37 \mathrm{gm})$, pod length $(7.30 \mathrm{~cm})$, harvest index $(39.43 \%)$, days of maturity $(65$ days $)$ in variety IPM- 0203 . The maximum biological yield $(24.50 \mathrm{gm})$, dry weight per plant $(30.30$ $\mathrm{gm})$, test weight $(50.50 \mathrm{gm})$, treatment $\mathrm{T}_{4}$ (Brassinolide $\left.0.50 \mathrm{ppm}\right)$ in variety IPM- 0203 . The maximum day to $50 \%$ flowering (40.67 days) in treatment $\mathrm{T}_{2}$ (salicylic acid $200 \mathrm{ppm}$ ) in variety IPM- 0203.

\section{Introduction}

In India, production of pulses is around 13.515 million tonnes during the last decade, while annual domestic demand is 18-19 million tonnes. The yield of pulses has remained virtually stagnant for the last 40 year $(539 \mathrm{~kg} / \mathrm{ha}$ in 1961 to $544 \mathrm{~kg} / \mathrm{ha}$ in 2001 to $696 \mathrm{~kg} / \mathrm{ha}$ in 2013-14). India is short of supply by 2 to 3 million tonnes annually (FAOSTAT, 2013-14). In India, it is the third important pulse crop after chickpea and pigeon pea, green gram is cultivated in state of Rajasthan, Madhya Pradesh, Punjab, Haryana, U.P., Maharashtra, Karnataka,
Andhra Pradesh and Tamil Nadu. Green gram is the most important pulse crop of India and grown in about 3.42 million hectare area with 1.72 million tonnes of production with average yield of $696 \mathrm{~kg} / \mathrm{ha}$.

In Uttar Pradesh, it is being cultivated in an area of 0.89 lakhs hectare with 0.62 lakhs tonnes production (GOI, 2014). The main reason of low productivity of the green gram is cultivation on marginal and sub-marginal lands with no use of recommended dose of fertilizers. 
Flowering is important parameter that is directly related to yield and productivity of plants. Salicylic acid has been reported to induce flowering in a number of plants. Different plant species including ornamental plant Sinningia speciosa flowered much earlier as compared to the untreated control, when they received an exogenous foliar spray of salicylic acid (Martin-Max et al., 2005). Foliar sprays of salicylic acid in green gram increase seed yield plant ${ }^{-1}$ (Singh et al., 1980). In addition application of salicylic acid as a 100 ppm concentration increase increase number of pods plant ${ }^{-1}$, number of seeds pod, seed weight plant, and seed yield/ha (Sujatha 2001). Jaykumar et al., (2008) reported that the application of $125 \mathrm{ppm}$ salicylic acid to black gram plants increase seed yield.

Plant growth regulators are one of the most important factors for increasing higher yield in leafy vegetables. Application of growth regulators has good management effect on growth and yield of field crops. Hormones regulate physiological process and synthetic growth regulators may enhance growth and development of field crops thereby increased total dry mass of a field crop (Das and Das, 1996; Abd-el-Fattah, 1997; Chibu et al., 2000; Dakua, 2002; Islam, 2007; Cho et al., 2008).

These plant growth regulators (PGRs) in general, help to increase the number of flowers on the plant when applied at the time of flowering. The flower and pod drop may be reduced to some extent by spraying various growth regulators on foliage (Ramesh and Thirumuguran, 2001). The foliar application of PGRs and urea significantly increased seed yield per plant (Patil et al., 2005).

Brassinolide had a significant influence on growth and yield of the crop. The growth in terms of plant height, LAI and dry matter accumulation per unit area were significantly higher in the treatments where the plants got nutrients and Brassinolide. Foliar fertilization had significant effect on the main yield component, i.e., number of pods per plant; though, other yield components were statistically at par. Foliar application of Brassinolide had a distinct effect to increase the yield of green gram crop (Sengupta and Tamang, 2015).

Zn enriched seeds performs better with respect to seed germination, seedling growth and yield of crops. The foliar application of $\mathrm{Zn}$ modulates the plant growth and production in mungbean including straw yield and crude protein in seeds has also indicated that foliar application of $\mathrm{Zn}, \mathrm{Mn}, \mathrm{Fe}$ and $\mathrm{Mg}$ significantly increased growth and yield in mungbean plants. Recently, it is suggested that salinity induced decrease in leaf, stem and root dry weights could be diminished with applications of $\mathrm{Zn}$ on pistachio seedlings (Henselova et al., 2010).

Boron is mainly required for reproduction of plant and germination of pollen grain. Primary role concerned with Ca metabolism, keeps $\mathrm{Ca}$ in soluble form within the cell and act as a regulator of $\mathrm{K} / \mathrm{Ca}$ ratio, constituent of cell membrane and essential for cell division. It is also primarily needed to maintain the growth of apical growing point.

\section{Materials and Methods}

A field experiment was conducted on research farm of department of biological Science, SHIATS-DU Allahabad, (U.P.) India. The soil of experimental area falls in order Inceptisol and the experimental field is alluvial in nature. The design applied for statistical analysis was carried out with randomized block design having row to row distance was maintained at $30 \mathrm{~cm}$ and plant to plant distance was $10 \mathrm{~cm}$, during the course of experiment, observations were recorded as mean values of the data. 


\section{Different type of treatments}

In this experiment, 2 varieties IPM-0203 and Ganga-8 and 6 treatments with respective control at different concentration was used before the flowering in green gram. This treatment $\mathrm{T}_{0}$ control, $\mathrm{T}_{1}$ Salicylic acid 100 ppm (Kuttimani and Velayutham., 2011), $\mathrm{T}_{2}$ Salicylic acid $200 \mathrm{ppm}$ (Ali and Mahmoud., 2013), $T_{3}$ Brassinolide $0.25 \mathrm{ppm}$ (Shil et al., 2007), $\mathrm{T}_{4}$ Brassinolide $0.50 \mathrm{ppm}$ (Maity and Bera 2009), $\mathrm{T}_{5}$ zinc $\left(\mathrm{ZnSo}_{4}\right) 100 \mathrm{ppm}$ (Samreen et al., 2013) and $\mathrm{T}_{6}$ Boron $100 \mathrm{ppm}$ (Mondal et al., 2011) was used this experiment.

\section{Results and Discussions}

\section{Effect of brassinolide, salicylic acid, $\mathrm{Zn}$ and} boron on flowering

The effect of plant growth regulators and micro-nutrient on days to $50 \%$ flowering Variety IPM-0203 in T2 (Salicylic acid 200ppm) flowered significantly earlier than (40.67 days) than the variety Ganga-8 in T6 (Boron 100ppm) (46.33 days). Similar result found as Ananthi and Gomathy (2011) studied the flowering and yield components were significantly increased by the application of Salicylic acid 200ppm. The maximum Number of flowers plant ${ }^{-1}$ was observed in variety IPM-0203 - 39.3 flowers in T3 (Brassinolide 0.25ppm), where as the minimum was observed in variety Ganga- 8 25.7 flowers in T0 (control), under all the treatments. Similar result Brassinolide $0.25 \mathrm{ppm}$ in general, help to increase the number of flowers on the plant when applied at the time of flowering (Ananthi et al., (2012). The maximum Flower fruit ratio \% was observed in variety IPM-0203 - 72.67 in $\mathrm{T}_{3}$ (Brassinolide 0.25ppm), where as the minimum was observed in variety Ganga- 8 49.00 in $\mathrm{T}_{0}$ (Control). Over all the treatment $\mathrm{T}_{3}$ showed best response. Similar result the flower and pod drop may be reduced to some extent by spraying Brassinolide growth regulators on foliage (Ramesh and Thirumuguran, 2001) Ananthi and Gomathy, (2011). The maximum Pollen viability $\%$ was observed in variety IPM-0203 - 70\% in $\mathrm{T}_{3}$ (Brassinolide $0.25 \mathrm{ppm}$ ), whereas the minimum was observed in variety Ganga- 8 $50.67 \%$ in $\mathrm{T}_{5}(\mathrm{ZnSo} 4)$. Over all the treatment $\mathrm{T}_{3}$ showed best response. Brasinoloide $0.25 \mathrm{ppm}$ increasing of pollen viability of black gram, similar results were also reported by Panday et al., (2013).

\section{Effect of brassinolide, salicylic acid, $\mathrm{Zn}$ and} boron on yield

The effect of plant growth regulators and micro-nutrient on the maximum number of pods per plant was observed in variety IPM0203 - 28.7 pods in T3 (Brassinolide $0.25 \mathrm{ppm}$ ), whereas the minimum was observed in variety Ganga- $8-13.3$ pods in T0 (Control), under all the treatments. Similar result that growth regulator spray significantly influenced number of pods per plant, maximum number of pods per plant was recorded with $0.1 \% \mathrm{HA}+0.1 \mathrm{ppm} \mathrm{BR}$. The influence of BA on number of seeds per pod was explained by Upadhyay (1994) and Ananthi and Vanangamudi (2013). The maximum number of Pod Weight per plant was observed in variety IPM-0203 - 11.37 in T3 (Brassinolide 0.25ppm), whereas the minimum was observed in variety Ganga- 8 7.23 in T0 (Control), under all the treatments. The influence of BA on Pod Weight per plant (gm) was explained by Ananthi and Vanangamudi (2013). The maximum Pod Length was observed in variety IPM-0203 7.30 in T3 (Brassinolide 0.25ppm), whereas the minimum was observed in variety Ganga$8-5.20$ in T0 (Control), under all the treatments, similar result brasinoloide increasing of pod length of black gram. 
Table.1 Effect of plant growth regulators and micro-nutrient on flowering and yield parameters of green gram varieties

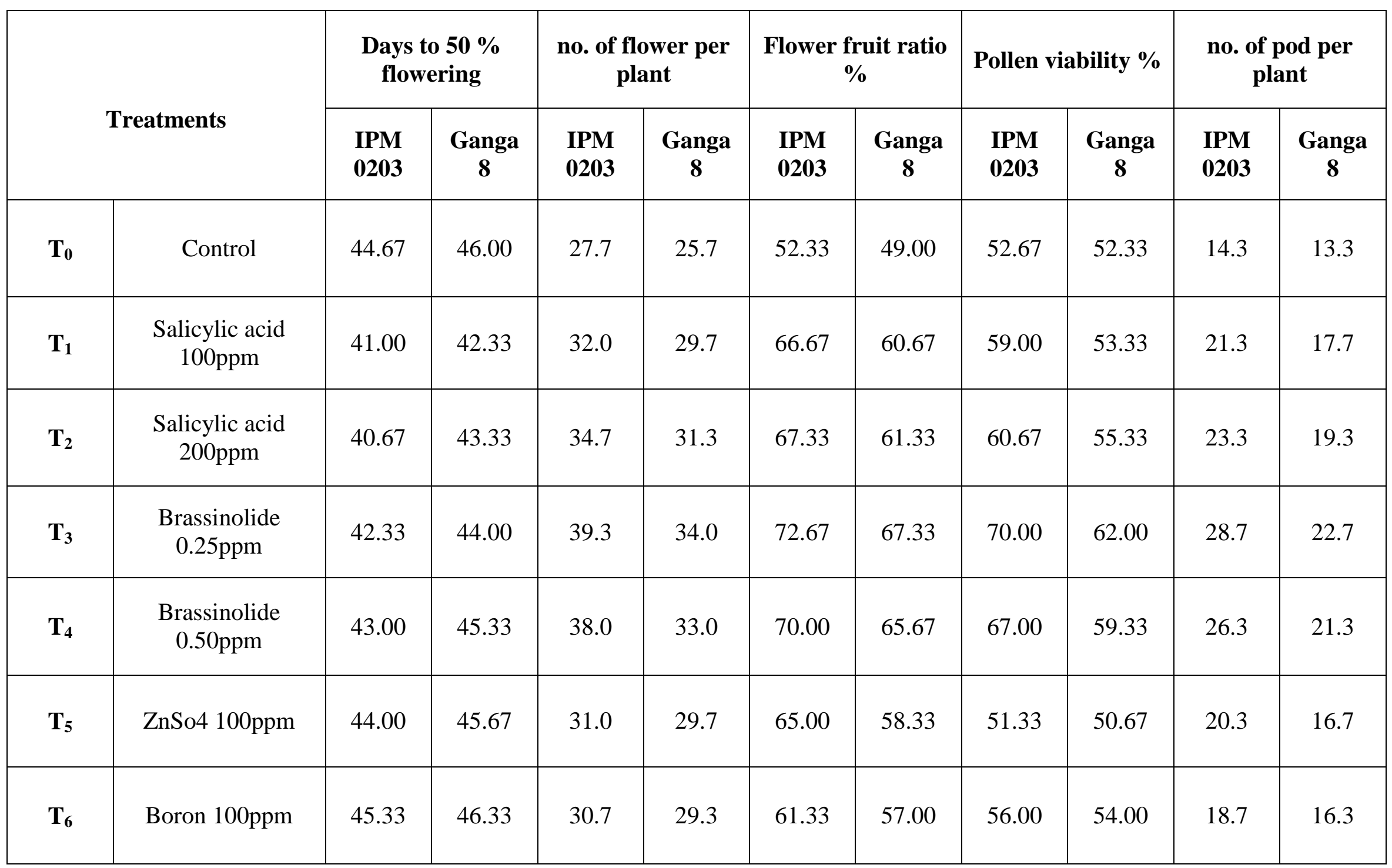


Table.2 Effect of plant growth regulators and micro-nutrient on flowering and yield parameters of green gram varieties

\begin{tabular}{|c|c|c|c|c|c|c|c|c|c|c|c|c|c|}
\hline & \multirow{2}{*}{ 'reatments } & \multicolumn{2}{|c|}{$\begin{array}{l}\text { Pod Weight } \\
\text { Plant }^{-1}(g)\end{array}$} & \multicolumn{2}{|c|}{$\begin{array}{l}\text { Pod Length } \\
(\mathrm{cm})\end{array}$} & \multicolumn{2}{|c|}{$\begin{array}{c}\text { Biological yield } \\
(\mathrm{g})\end{array}$} & \multicolumn{2}{|c|}{$\begin{array}{l}\text { Dry weight per } \\
\text { plant (g) }\end{array}$} & \multicolumn{2}{|c|}{$\begin{array}{c}\text { Test weight } \\
(\text { gm) } 1000 \text { seed }\end{array}$} & \multicolumn{2}{|c|}{$\begin{array}{c}\text { Harvest Index } \\
\%\end{array}$} \\
\hline & & IPM & Ganga & IPM & Ganga & IPM & Ganga & IPM & Ganga & IPM & Ganga & IPM & Ganga \\
\hline $\mathbf{T}_{0}$ & Control & 8.33 & 7.23 & 5.70 & 5.20 & 19.1 & 18.7 & 25.8 & 24.4 & 43.4 & 42.5 & 22.43 & 20.66 \\
\hline $\mathbf{T}_{1}$ & $\begin{array}{l}\text { Salicylic acid } \\
\text { 100ppm }\end{array}$ & 9.90 & 8.90 & 6.00 & 5.70 & 21.9 & 20.1 & 27.6 & 25.5 & 46.7 & 42.4 & 27.99 & 28.53 \\
\hline $\mathbf{T}_{2}$ & $\begin{array}{l}\text { Salicylic acid } \\
\text { 200ppm }\end{array}$ & 9.90 & 8.97 & 6.20 & 6.00 & 22.8 & 20.2 & 29.2 & 27.1 & 47.5 & 44.6 & 30.47 & 26.54 \\
\hline $\mathbf{T}_{\mathbf{3}}$ & $\begin{array}{c}\text { Brassinolide } \\
0.25 \mathrm{ppm}\end{array}$ & 11.37 & 10.00 & 7.30 & 6.73 & 24.5 & 22.3 & 29.8 & 27.6 & 49.7 & 45.3 & 39.43 & 34.34 \\
\hline $\mathbf{T}_{4}$ & $\begin{array}{c}\text { Brassinolide } \\
0.50 \mathrm{ppm}\end{array}$ & 10.80 & 9.63 & 6.87 & 6.53 & 23.6 & 21.8 & 30.3 & 28.0 & 50.5 & 46.5 & 35.77 & 31.17 \\
\hline $\mathbf{T}_{\mathbf{5}}$ & ZnSo4 100ppm & 9.57 & 8.23 & 6.30 & 6.00 & 21.9 & 19.8 & 25.4 & 24.0 & 48.4 & 45.0 & 25.47 & 22.93 \\
\hline $\mathbf{T}_{6}$ & Boron 100ppm & 9.37 & 8.10 & 5.90 & 5.67 & 21.6 & 19.4 & 26.4 & 26.1 & 48.1 & 43.3 & 23.49 & 20.30 \\
\hline
\end{tabular}


The present results are in agreement with Panday et al., (2013). The maximum Biological Yield was observed in variety IPM-0203 - 24.50 in T4 (Brassinolide $0.50 \mathrm{ppm})$, whereas the minimum was observed in variety Ganga-8 - 18.70 in T0 (Control), under all the treatments. Similar result found by the average yield increased with increased number of application of nutrients and brassinolide. Crop performance was not good in the control treatment thus, the yields per hectare was significantly lower than that obtained in other treatments. This result in conformity with the findings reported by Fariduddin, (2004), Sengupta and Tamang (2015). The maximum Dry Weight per Plant was observed in variety IPM-0203 - 30.30 in T4 (Brassinolide 0.50ppm), whereas the minimum was observed in variety Ganga-8 24.00 in $\mathrm{T} 5$ (ZnSo4 100ppm), under all the treatments. Further there was a significant difference in all the varieties under different treatments. The results are in conformity with those of Chovatia et al., (1993); Shrinivas and Mohammad (2002) and Shukla and Dixit (1996). The maximum Test Weight was observed in variety IPM-0203 - 50.50 in T4 (Brassinolide $0.50 \mathrm{ppm}$ ), whereas the minimum was observed in variety IPM-0203 - 42.50 in T0 (Control), under all the treatments. Further there was a significant difference in all the varieties under different treatments. Similar results are in conformity with those of Shrinivas and Mohammad (2002). The maximum Harvest Index was observed in variety IPM-0203 - 39.43 in T3 (Brassinolide $0.25 \mathrm{ppm}$ ), whereas the minimum was observed in variety Ganga-8 20.30 in T6 (Boron 100ppm), under all the treatments.

In conclusion, present investigation concludes that Plant growth regulators (PGRs) performs positively and improved flowering and yield parameters studied. The treatment $\mathrm{T}_{3}$ and $\mathrm{T}_{4}$ (Brassinolide 0.25 and $0.50 \mathrm{ppm}$ ) was found to be the best treatment. Thus it could be recommended for better flowering and production of green gram (Vigna radiata $L$.) variety IPM-0203.

\section{References}

Abd-el-Fattah, M. A. (1997). Effect of phosphorus, boron, $\mathrm{GA}_{3}$ and their interaction on growth, flowering, pod setting, abscission and yield of broad bean. Alexandria J. Agril. Res., 42: 311-332.

Ali, E. A.; And Mahmoud, Adel M. (2013) Effect of foliar spray by different salicylic acid and zinc concentrations on seed yield and yield components of mungbean in sandy soil. Asian Journal of Crop Science; Vol. 5 Issue $1, \mathrm{p} 33$.

Ananthi K. And Gomathy M. (2011) Effect of bioregulators on the yield of greengram. International Journal Of Forestry And Crop Improvement; 2 (1): 12-15

Ananthi K. and Vanangamudi Mallika, (2013) foliar application of humic acid with brassinosteroid on chlorophyll content and yield of green gram [vigna radiata (1.) wilczek] Legume Res., 36 (3): 241 - 244,

Ananthi K., Karuppaiya M., Anand T. and Gomathy M. (2012) Effect of humic acid with bioregulators on the yield of green gram [Vigna radiata (L.) wikzek] Asian J. Bio Sci., 7 (1) p. 30-33.

Chibu, H., Shibayama, H. and Arima, S. (2002). Effects of Chitosan application on on the shoot growth of rice and soybean. Japn. J. Crop Sci. 71: 206-211.

Cho, M. H., No, H. K. and Prinyawiwatkul, W. (2008). Chitosan treatments affect growth and selected quality of sunflower sprouts. $J$. Food Sci. 73: 570-577.

Chovatia, P. K., Ahlawat, R. P. S. and Trivedi, S. J. 1993. Growth and yield of summer green gram (Phaseolus radiata) as affected by different date of sowing, rhizobium inoculation and level of phosphorus. Indian J. Agron. 38(3): 492-494.

Dakua, M. F. (2002). Effect of CI-IAA, TNZ-303 and GABA on growth, yield and yield contributing characters of lentil. M. S. Thesis, Dept. Crop Bot., Bangladesh Agric. Univ., Mymensingh.

Das, B. C. and Das, T. K. (1996). Studies on the response of $\mathrm{GA}_{3}$, NAA and Etherl on the vegetative growth and yield of pumpkin. 
Orisssa J. Hort., 24: 74-78.

FAO STAT (2014) Online Interactive Database on Agriculture. FAO STAT. www.fao.org.

Fariduddin, Q., Ahmad, A. and Hayat, S. (2004) Responses of Vigna radiata to foliar application of 28-homobrassinolide and kinetin. Biologia Plantarum, 48: 465-68.

GOI (2014) Data base on Indian Agriculture, Department of Agriculture and Cooperation. http:// dacnet.nic.in.

Henselova, M. and Slovakova, L. (2010) Effect of Foliar Fertilizer Campofort Special-zn and Plant Growth Regulator Rastim 30 dkv On Growth, yield Components and Protein content in Mung bean Plants Acta Agronomica Hungarica, 58(1), pp. 37-47.

Islam, M. M. (2007). Effect of GABA on growth, yield and yield contributing characters of sesame. M. S. Thesis. Dept. Crop Bot., Bangladsh Agric. Univ., Mymensingh.

Jaykumar, P., Velu, G., Rajendran, C., Amutha, R., Savery, M.A.J.R. and Chitambaram, S. (2008). Varied response of blackgram (Vigna mungo) to certain foliar applied chemicals and plant growth regulators. Legume Res. 31: 110-113.

Kuttimani, R.; Velayutham, A. (2011) Foliar application of nutrients enhances the yield attributes and nutrient uptake of greengram. Agricultural Science Digest; Vol. 31 Issue 3, p202

Maity U. and Bera A.K. (2009) Effect of exogenous application of brassinolide and salicylic acid on certain physiological and biochemical aspects of green gram (vigna radiata 1 . wilczek) Indian J. Agric. Res., 43 (3): 194199

Martin-Mex R, Villanueva-Couob E, HerreraCampos T, Larque-Saavedra A. (2005). Positive effect of salicylates on the flowering of African violet. Sci. Hort. 103: 499-502.

Mondal, M. M. A.; Rahman, M. A.; Akter, M. B.;
Fakir, M. S. A. (2011) effect of foliar application of nitrogen and micronutrients on growth and yield in mungbean Legume Research: An International Journal; Vol. 34 Issue 3, p166

Patil, S.N., Patil, R.B. and Suyawanshi, Y.B. (2005). Effect of foliar application of plant growth regulators and nutrients on seed yield and quality attributes of mugbean [Vigna radiata (L.) Wilezeli]. Seed Res., 33: 142-145.

Ramesh, K. and Thirumurugan, V. (2001). Effect of seed pelleting and foliar nutrition on growth of soybean. Madras Agric. J., 88: 465-468.

Samreen Tayyeba, Humaira, Ullah Shah Hamid, Ullah Saleem, Javid Muhammad (2013) Zinc effect on growth rate, chlorophyll, protein and mineral contents of hydroponically grown mungbeans plant (Vigna radiata) Arabian Journal of Chemistry (2013)

Sengupta K. And Tamang D. (2015) Response of green gram to foliar application of nutrients and brassinolide Journal Crop and Weed, 11(1):43-45

Shil N.C., Noor S. and Hossain M.A. (2007) Effects of Boron and Molybdenum on the Yield of Chickpea J Agric Rural Dev 5(1\&2), 17-24.

Shrinivas, M. and Mohammad, S. 2002. Performance of green gram (Vigna radiata L.) and response function as influenced by different levels of nitrogen and phosphorus. Crop Res. 24(3): 458-462.

Shukla, R. K. and Dixit, R. S. 1996. Effect of rhizobium inoculation, plant population and phosphorus on growth and yield of summer green gram (Phaseolus radiata L.). Indian J. Agron. 41(4): 611-615.

Sujatha, K.B. (2001). Effect of foliar spray of chemicals and bioregulators on growth and yield of green gram (Vigna radiata (L.) Silezek). M.Sc. (Ag.) Thesis, Tamil Nadu Agricultural University, Coimbatore.

\section{How to cite this article:}

Dilip Matwa, K.P. Rao, J.S. Dhewa and Rajveer. 2017. Effect of Plant Growth Regulators (PGRs) and Micronutrients on Flowering and Yield Parameters of Green Gram (Vigna radiate L.). Int.J.Curr.Microbiol.App.Sci. 6(4): 2350-2356.

doi: https://doi.org/10.20546/ijcmas.2017.604.274 